\title{
Multicultural Education Reinforcement for Early Childhood
}

\author{
Ahmad Marzuki*, Nurul Imamah, Munif, M. Anang Sholikhudin, Ahmad Makruf \\ \{marzuki@yudharta.ac.id\} \\ University of Yudharta Pasuruan, Indonesia
}

\begin{abstract}
This research specifically photographs the two kindergarten schools, Namely Ceria Kindergarten and Golden Kids. The two schools have compound school residents. Not only Moslem but some school residents are Christian as well as Catholic. Students come from different religious and ethnic backgrounds. In 2018 there were about 13 nonMuslim students such as Christians and Catholics out of a total of 129 students. In addition to their religious backgrounds also come from different tribes, some from Chinese, Madura, and Javanese. Similarly, educators in the institution are Muslim and there are also non-Moslem out of a total of 15 teachers. In carrying out learning activities by strengthening multicultural education to its students by using three approaches, namely contribution approach, social action approach, and habituation shorting to form the character of social care, environmental care, cooperation, and tolerance for children.
\end{abstract}

Keywords: Multicultural Education; Childhood; Education

\section{Introduction}

James Banks states that the notion of multicultural education as an education for people of colour.[1] Multicultural education is related to the attitude of "caring" and wanting to understand (difference), or "politics of recognition" political recognition against people from minority groups.[2] Thus in the context of this research, Multicultural education is used as an instrument material covering subjects such as: tolerance; social care, harmony and themes about ethno-cultural and religious differences for the process of strengthening behaviour for early childhood.

Early childhood is a period of life from birth to the age of eight. The period of determination in developing the child's brain, because this period is the initial foundation in the learning stage. The National Association for the education of young children (NAEYC) explains that this period is a very vulnerable age in human life which is the age from birth to 8 years.[3] Early age is the golden age. The results showed that a child up to the age of four had an achievable level of intelligence capability of $50 \%$. By the age of eight it reaches $80 \%$ and the remaining about $20 \%$ is earned by the time the child is eight years old and above.

As is the case in Ceria Pandaan Kindergarten which is one of the early childhood educational institutions in which there are not only school residents who are Muslim but there are some school residents who are Christian as well as Catholic. One way that is done in Ceria Pandaan kindergarten for multicultural education is for teachers to directly practice how they are concerned in an event with their different religions. As in the event "Takjil Ceria" which is done 
during the month of Every Ramadan. It aims to give reinforcement [4] of multicultural education to children and teach them to share even though their religion, tribe, and culture are different.

\section{Research Methods}

This research uses qualitative research methods with a case study approach. This research was conducted in two locations namely Ceria Kindergarten and Golden Kids Pandaan Kindergarten. TK Ceria is located on Jln. Raya Malang-Pasuruan No.60 Kali Tengah, Karang Jati Pandaan Pasuruan67156. Meanwhile, Golden Kids Pandaan kindergarten is located in Perum Batu Mas Blok E 1-07 Petungasri Pandaan 67156. Data collection techniques use indepth interviews, participant observation and documentation. While data analysis techniques use category collection, direct interpretation, pattern formation and developing naturalistic generalizations.

\section{Results and Discussion}

Ceria kindergarten and Golden Kids Pandaan kindergarten have students who come from different religious and ethnic backgrounds. In 2018 there were about 13 non-Muslim students such as Christians and Catholics out of a total of 129 students. In addition to their religious backgrounds also come from different tribes, some from Chinese, Madura, and Javanese. Similarly, educators in the institution are Muslim and there are also non-Moslem out of a total of 15 teachers.

Table 1. Student Data

\begin{tabular}{llllll}
\hline $\begin{array}{l}\text { School } \\
\text { Name }\end{array}$ & Moslem & Christian & Catholic & Buddhist & Total \\
\hline $\begin{array}{l}\text { Golden Kids } \\
\text { Kindergarten }\end{array}$ & 116 & 7 & 4 & 2 & 129 \\
\hline $\begin{array}{l}\text { Ceria } \\
\text { Kindergarten }\end{array}$ & 120 & 10 & 2 & 3 & 135 \\
\hline
\end{tabular}

Table 2. Teacher Data

\begin{tabular}{lllll}
\hline School Name & Moslem & Christian & Catholic & Total \\
\hline $\begin{array}{l}\text { Golden Kids } \\
\text { Kindergarten }\end{array}$ & 9 & 2 & 4 & 15 \\
\hline Ceria Kindergarten & 10 & 5 & 2 & 17 \\
\hline
\end{tabular}

To strengthen multicultural education the two schools, use three approaches, namely contribution approaches, sosial action approaches and habituation approaches.

\subsection{Contribution Approach}

The contribution approach is an approach that is carried out by selecting compulsory textbooks or recommendations and certain activities such as the great days of statehood and religion from different cultures.[5] This approach aims to increase knowledge about group 
diversity so that it can be developed by offering distinctive content in various variants of education.

One of the contribution approaches in the implementation of Multicultural Education Reinforcement in Cheerful Kindergarten religious programs is the distribution of zakat fitrah where this activity is attended by all Ceria kindergarten students both Moslem and Students who are Christians, and Catholics who are happy to participate in the activity. However, the distribution of zakat fitrah is designed as a social service[6] activity for students who are religious other than Muslim. This activity is not only attended by students, but the parents also participate in this activity.

Meanwhile, in kindergarten Golden Kids zakat distribution activities are followed by students who are Muslim only because students who are Christian Also Catholic are taken off during Ramadan. This aims to keep the child focused when learning about his religion.

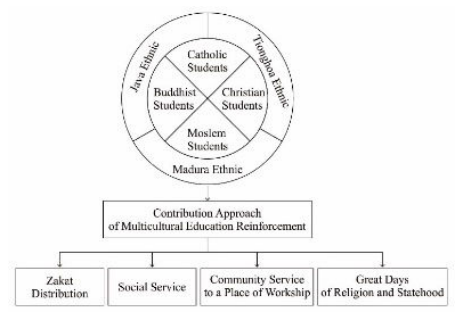

Fig 1. Model reinforcement contribution approach

\subsection{Social Action Approach}

A social action approach is an approach that combines or combines a transformative approach with various activities to make social change. This approach aims to enrich students' skills in social action, such as cultural differences, diversity reconciliation and conflict resolution[5]. One of the ways that cheerful kindergarten in this approach is the distribution of cheerful takjil carried out in Ramadan this activity is followed by all students and guardians of students both Moslim and Christian As well as Catholics with the record of students or guardians of students who are Christian, Catholics design to participate in this activity. While in kindergarten Golden Kids is done by collecting plastic waste from the house that will be sold which then the money will be donated to the nursing home. This is done with the aim of caring for students in the surrounding environment to minimize household waste as well as teach children the importance of helping.

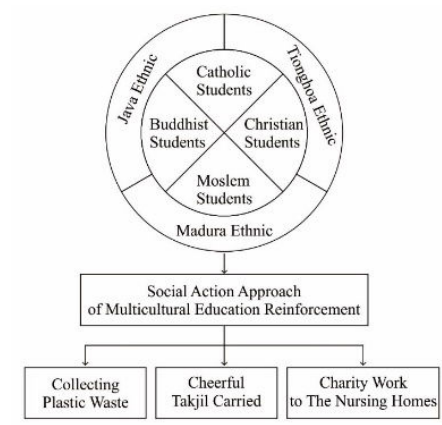

Fig 2. Model reinforcement social action approach 


\subsection{Habituation Approach}

The habituation approach is an approach that contains experience and in it there is repetition.[7] One example of an activity that uses a habituation approach through a ceremony held every Monday is attended by the entire board of teachers and students and prays before and after learning according to their respective religions. And this activity is guided by their respective religious teachers.

Then through the character pillar activities that are carried out every day in school. Ceria Kindergarten chose a verbal way to implement Multicultural Education Reinforcement with Knowing, Feeling and Acting stages. At this stage, the teacher explains in detail about the character that you want to achieve e.g. tolerance. At this stage, the teacher also gives an example through illustrations that have been made about the character of tolerance that is then played by students. The process is carried out daily to form the character of the child. While non verbal is done by introducing directly how they are related in an activity conducted together in school such as ceria takjil activities conducted in Ramadan, Maulud Nabi activities, Easter activities, zakat fitrah activities and other activities.

In joint activities conducted in the school, the school gives the student's guardian the freedom to include his or her child in the activity. It is through this activity that teachers teach how tolerance and social care should be had by every human being and through this activity also teachers exemplify how they work together in succeeding the activity. The teachings of religion give a very wide tolerance to all people in the world, so that there is no conflict between people. And allah is All-Knowing, All-Wise.

In addition to giving a direct example through joint activities, the multicultural attitude of students is seen during the learning activities. Like when the teacher instructs that every child is required to bring healthy food. If some of them do not bring supplies, the teacher gently offers to the friend who brought to share the supplies brought to the friend who did not bring. And immediately the teacher gave Reinforcement a smile and a thumbs up to students who wanted to share it with other friends. This is a way for teachers to instill social care in children.

Golden Kids Kindergarten has the same way as Cheerful Kindergarten in implementing Multicultural Education Reinforcement in a verbal way that is with knowing stage. Feeling and Acting. [8] This is in accordance with the opinion of Thomas Lickona, a good character consisting of Knowing, Feeling and Acting. These three components are important in character formation. At the Knowing stage there are six aspects that need to be emphasized namely moral awareness, knowledge of moral values, determination of perspective, moral thinking, decision making and personal knowledge. At the Feeling stage the stressed aspects are conscience, selfesteem, empathy, loving good things, self-control and humility. And at the Acting stage the things that are emphasized are competence, desires and habits.[8] The three aspects must be done in a balanced manner because they are intertwined with each other. These three aspects must be processed in full in order for the desired character to be achieved to the maximum.

Meanwhile, Golden Kids kindergarten has a different way of implementing non-verbal Multicultural Education Reinforcement by giving hugs, smiles, and rewarding pockets in the form of smile and sad stickers given inside and outside learning. In kindergarten Golden Kids has never held a joint activity such as Easter activities attended by students who are Christian, Catholic or Muslim. Religious celebrations are carried out by adherents of their respective religions. This is intended so that each child is focused and solemn' in their own religious celebrations.

The implementation of positive Reinforcement such as flattery, praise, gifts and so on is more applied by Golden Kids kindergarten teachers at the early childhood level especially compared to giving negative Reinforcement such as giving punishment, sanctions and others. 
This shows that the learning characteristics of children of this age are children learning through play, children learning by building their knowledge of children learning scientifically and children learning best if what is learned by the child is considered all aspects of child development meaningful, and interesting. Every child will love fun learning while playing and be very affected by the gift or award given. Based on Skinner's theory application to learning that if necessary rewards or rewards need to be given to students.

Reinforcement can be used as a means to recognize good and bad things, can also build children's character early for the future. In addition, Reinforcement can also build the value of the child's confidence as well as the independence of the child. If the child has obtained the appropriate Reinforcement from the surrounding adults, usually the child will repeat the act in the future.

This can be seen in multicultural education activities or character pillars in Cheerful Kindergarten and Golden Kids Pandaan between teachers and children well intertwined, teachers understand at the time how children should get Reinforcement. Actually, Reinforcement is not something that should be in the form of expensive objects. Reinforcement can be done with the easiest thing that is to say good, give a smile as well as flattery and praise. Because if a child is accustomed to getting Reinforcement in the form of expensive objects then they will do a good thing just to get a reward.

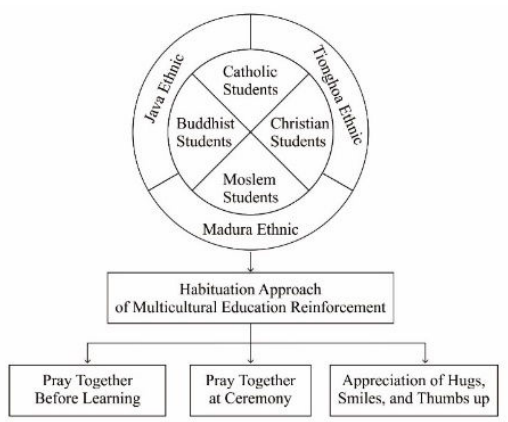

Figure 3. Model reinforcement habituation approach

\section{Conclusion}

The implementation of Multicultural Education Reinforcement in Cheerful Kindergarten and Golden Kids Pandaan Kindergarten is carried out in two ways, namely through verbal and nonverbal through three approaches, namely social action approach, habituation and contribution. The verbal way has the same stage both Kindergarten Ceria and Kindergarten Golden kids Pandaan namely Knowing, Feeling, and Acting.

Whereas non-verbal means are done in different ways. Ceria kindergarten in addition to using rewards or gifts prefers to directly provide a direct example through joint activities held in schools. While Golden Kids Kindergarten uses pocket rewards or gifts given to children. And the gift given is not an object or item, but rather a gift is given in the form of hugs, smiles, thumbs up and others. 


\section{References}

[1] Banks J A 1993 Multicultural education: Historical development, dimensions, and practice Rev. Res. Educ. 19 3-49

[2] Azra A 2007 Identitas dan Krisis Budaya, Membangun Multikulturalisme Indonesia Jakarta Pustaka Indones.

[3] Bodrova E and Leong D J 2001 Tools of the Mind: A Case Study of Implementing the Vygotskian Approach in American Early Childhood and Primary Classrooms. Innodata Monographs 7.

[4] McLeod S 2015 Skinner-operant conditioning Retrieved from

[5] Sulalah P M D N 2011 Universalitas Kebangsaan

[6] Karim A 2015 Dimensi Sosial dan Spiritual Ibadah Zakat ZISWAF J. Zakat dan Wakaf 2 1-22

[7] Andiarini S E and Nurabadi A 2018 Implementasi program penguatan pendidikan karakter melalui kegiatan pembiasaan dalam peningkatan mutu sekolah JAMP J. Adm. dan Manaj. Pendidik. 1238 44

[8] Lickona T 2012 Educating for character: Mendidik untuk membentuk karakter Jakarta Bumi Aksara $20-8$ 